\title{
Effectiveness of the Covid-19 Economic Stimulus Packages: Viewpoints from Malaysian Young Entrepreneurs
}

\author{
TAN-CHIN LIM ${ }^{1}$, LIAN KEE PHUA ${ }^{2 *}$, SIN YIN TEH ${ }^{3}$, CHAR-LEE LOK ${ }^{4}$ \\ School of Management, UNIVERSITI SAINS MALAYSIA, MALAYSIA. \\ ${ }^{1}$ E-mail: tclim@usm.my \\ 2E-mail: phualk@usm.my \\ ${ }^{3}$ E-mail: tehsyin@usm.my \\ ${ }^{4}$ E-mail: lokcl@usm.my
}

\begin{abstract}
The objective of this study is to investigate the effectiveness of economic stimulus packages of COVID-19 for small-medium enterprises (SMEs) in Malaysia, specifically on the young entrepreneurs' age 40 and below to offer some views on financial measures that should be prioritised and strengthened to lessen the burden of those young entrepreneurs who are severely affected during the pandemic. Data collected mainly from the survey of 25 industry players on their views on the Malaysian government's stimulus packages, announcements and reports. Analysis of the findings serves as the basis for deriving the viewpoints and reflections of this paper. The result shows that most interviewees welcome a six-month wage subsidy program, bank loan instalment moratorium and company tax deferment. Respondents commented that tax incentives on certain expenses are not as beneficial as that spending is luxurious. Feedback shows a delay in receiving the subsidies by some respondents and concerns on their ability to pay tax and loan instalments in the future when the government lifted the incentives as they expect a longer time is needed to boost demand. From the positive impacts, respondents viewed optimistically the Malaysian government's stimulus packages and complimented that as one of the best government strategies.
\end{abstract}

Keywords: Young Entrepreneurs; SMEs; COVID-19; Economic Stimulus Package

JEL Classification: H25, H84 


\section{Introduction}

The year 2020 is a tragic eventful year for the whole world. COVID-19 pandemic wrecked the entire world, causing an uproar, unprecedented, uncountable degree of severity and worrying death tolls and destructing businesses. Many countries were in total lockdown with the hope to contain the spread of the virus in the absence of a vaccine. On the 25th of January 2020, Malaysia confirmed its first COVID19 case. Within a short period of time, the cases escalated drastically, and eventually, the Malaysian government took the initiative to impose and enforce a restricted Movement Control Order (MCO) on 18th of March 2020. Most businesses were put to a halt as they were not allowed to operate except for businesses providing necessities such as essential food and health care. The national income was severely affected. The International Monetary Fund (IMF), initially forecasted Malaysia 2020's gross domestic product (GDP) at $-1.7 \%$, has revised its forecast of GDP to a lower -3.8\% year-on-year basis due to the adverse impact of COVID-19 than its original anticipation (The Edge Markets, 2020).

To restore and preserve Malaysia's economy, a few economic stimulus packages were launched by the Malaysian government under the Prihatin Rakyat Economic Stimulus Package (PRIHATIN) and Short-term Economic Recovery Plan (PENJANA). The PRIHATIN package was introduced on the 27th of February 2020 and had been reviewed and enhanced to a total value of RM250 billion (US\$58 billion). At the same time, the PENJANA was introduced due to the augmented severity of the economic downturn in Malaysia. As of September 2020, Malaysia has issued over RM290 billion (US\$67 billion) worth of incentives since February 2020 to revive its ailing economy, and they aim to provide immediate assistance to lessen the burden of its people, especially those who are affected during the COVID 19 pandemics.

Among all types of businesses, SMEs were severely affected as they lack sufficient reserve of cash to a turnaround in this devastated business environment. After referring to feedback from associations and commerce chamber representing the SMEs, the Malaysian government has revised its package and offers more assistance to SMEs. Specific stimulus packages aimed to help the Malaysian SMEs face tight cashflow problems to pull through this hard time. Among the stimulus packages that are expected to benefit SMEs are the wage subsidy program (WSP), the deferment of monthly income tax instalment payments and the moratorium on loan instalment.

The WSP was offered and governed by the Social Security Organisation (SOCSO) as one of the government departments under the Ministry of Human Resources. This WSP aims to assist employers financially and at the same time, prevent employees from being retrenched. According to the SOCSO website, WSP scheme has benefited 281,469 applicants since its introduction on the 1st of April to the 20th of May 2020; SOCSO had approved $94 \%$ of total applications. Those who failed were mainly due to non-fulfilment of requirement, incorrect business registration number, wrong account number or dormant companies.

In addition, another strategy that aims to assist SMEs is the deferment of monthly income tax instalment payments. Apart from the postponement of tax instalment, companies that are affected by COVID-19 can revise their profit estimates for 2020 concerning monthly income tax instalment payments without penalty.

Financial institutions also provided assistance by granting moratorium for six-month loan instalment without penalty starting April to September. This aid has eased SMEs' critical situation.

It is no doubt that SME is a key driver in the Malaysian economy, where it is a preferred business establishment. 98.5\% of businesses were set up as SMEs in the year 2017 and accounted for two-thirds of the total employment market. The SMEs' contribution to national income is vital too, and it had contributed $38.5 \%$ to Malaysia's GDP in 2019. Given that the mandatory close down of business operations during the MCOs periods had a direct and immediate impact on the cash flows of most SMEs who rely on their daily operations to generate working capital, the effectiveness of the government assistance in relieving the financial crisis faced by SMEs is critical to the sustainability and survival of the businesses, particularly, SMEs that young entrepreneurs set up. 
Young entrepreneurs are perceived as lack of experiences as they are newcomers in the market. However, they are innovative with high adaptability towards digitalised businesses. It is important to understand their concerns and grievances to propose constructive feedback to the policymakers to assist them in sailing through this rough storm wave. Therefore, this study aims to investigate the effectiveness of economic stimulus packages of COVID-19 on Malaysia SMEs from the young entrepreneurs' point of view.

The rest of the article is organised as follows: Section 2 reviews the studies regarding the topic; Section 3 covers the methodology. The results and discussion are given in Section 4. Conclusions are drawn in the last section.

\section{Literature review}

Association of Chartered Certified Accountants (2020) conducted a global survey regarding COVID19 impact on businesses by involving approximately 100 countries with 10,000 respondents who were Chartered Accountants and other stakeholders of the Association of Chartered Certified Accountants (ACCA). Approximately $40 \%$ of respondents faced tight cashflow issues and anxious about meeting their debt obligations. Short-term survival is a primary challenge, particularly for small businesses. Pessimistically, business leaders forecasted an $80 \%$ dramatic plunge in the year-on-year revenue and profit as uncertainties exist. The business leaders of small organisations were even more pessimistic, anticipating a sharp $85 \%$ drop in revenue, with one-third of companies faced cash flow issue. Federal and state governments over the world have taken different strategies to manoeuvre through COVID19. According to the survey, surprisingly, only $17 \%$ agreed that the government's strategies were effective. A majority voted ambiguous or uncertain with the government's intervention strategies in assisting the ailing businesses.

Undeniably, the government's strategies could not be implemented successfully without the help of stakeholders such as banks as SMEs are eager to get loans from the bank to fill up the shortages of cash. However, banks' delay and rejection in obtaining a loan through the Special Relief Facility (SRF), which SMEs face, may eventually bring the operations to a halt due to the inadequate cash flows to run the businesses (Voon, 2020). Even with the government's help, SMEs are being encouraged to review and reshape their business models given that the new norm of consumers living and spending habits, the SMEs shall adopt other alternatives to run their businesses. The shift from physical shops to e-commerce business could maintain the sales of SMEs after the COVID-19 pandemic crisis as given the current social environment context. Consumers are making a smart choice by purchasing goods online and thus, limited the transmission chance of COVID-19 (Rahman \& Hassan, 2020).

One of our neighboring countries, Indonesia, is also facing the same crisis as us. A study conducted by (Effendi et al., 2020) has agreed that government support is crucial in motivating the SMEs to overcome their hardships. Government assistance to cope with the liquidity risk of SMEs, policies to support the low-income family household, and policies to secure employment who has been laid-off during this pandemic period as well as the smoothness of supply chain, are most welcomed by SMEs (Fitriasari, 2020).

The wave of COVID-19 pandemic has affected not only the developing countries, but developed countries as well. Take United States (U.S.) for instance, has allocated \$2 trillion of federal funds to mitigate the income risk and the adverse impact due to the COVID-19 lockdown by mainly transfer the funds to households and firms with the hope of stabilising the economic tragic (Bayer et al., 2020). Besides, the Canadian government has also granted a huge stimulus package with the total amounting to CDN\$82 billion (approximately RM 260 billion or US\$ 65 billion) in reducing the massive impact of COVID-19 pandemic on Canadians. Under this stimulus package, Canadian Emergency Wage Subsidy (CEWS) aims to support private sector businesses by giving out to firms that have lost at least $15 \%$ revenues in March 2020 to retain employees of the firms under payroll (Doorey, 2020).

During the Covid-19 pandemic, we ask: Is cash the king during the pandemic? The pandemic brings threats to operations and drastically impacts the cash flows for business survival. Holding sufficient 
cash flows is particularly relevant in an unpredictable environment because firms with low cash reserves levels during a recession will be susceptible to failure (Nason \& Patel, 2016). Therefore, it is essential to maintain healthy cash flows to buffer against the crisis. Younger firms that are relatively newly established are usually smaller and face stronger competition than traditional firms in the dynamic investment environment (Carpenter \& Petersen, 2002).

Smaller firms without strong assets backings are more difficult to get loans from financial institutions; the new and unproven projects also lead to higher cost of external financing than firms in traditional industries (Guiso, 1998). Therefore, these firms need to depend on owners to generate internal funds. Smaller firms are unlikely to benefit from the development of capital markets, and they are financially constrained and may be unable to access financial services due to significant fixed costs (Tsoukas, 2011). Consistent with González et al. (2013), the level of borrowings tend to be lower for younger firms that are managed by the founders. Similarly, Cooley \& Quadrini (2001) found that young firms have a limited amount of capital and external debt financing involves higher costs. Hence, the ability for younger entrepreneurs to gain financial supports during the pandemic is critical because healthy cash flows have significant, positive effects on the growth of new firms (Huynh \& Petrunia, 2010; Qureshi et al., 2020). In fact, small entrepreneurial firms are a crucial source of jobs and economic growth. However, they are more likely to miss profitable investment projects due to insufficient funds to exploit them, suggesting that financial constraints are a key determinant of entrepreneurial activities of small firms (Vithessonthi \& Tongurai, 2015).

\section{Methodology}

A total of 25 young entrepreneurs from SMEs were surveyed to seek their views pertaining to those stimulus packages launched by the government. All of them were aged 40 and below. Their opinions on the effectiveness of the government's stimulus package were recorded. We also asked their view on how government can fill up the deficit gap as a consequence of offering financial assistance, reduction of revenue collection as businesses are not performing well and also the drop in oil price, which affect the royalty paid by Petronas. Opinions were also gathered from discussion and forum on social media platforms to gain more viewpoints. Apart from that, statistical data were collected from the announcements and reports published by the Malaysia government authorities that are responsible and accountable for the economic stimulus packages. Analysis of the findings serves as the basis in deriving the viewpoints and reflections of this paper.

\section{Results and Findings}

Referring to Table 1, out of 25 respondents, 18 are female entrepreneurs, accounted for $72 \%$ of our survey sample. More than half are doing unincorporated businesses, namely sole proprietorship and partnership. Their business activities encompass retailing, trading, and servicing. Roughly two-thirds are operating with less than ten employees.

Not all stimulus packages are beneficial to young entrepreneurs. From the negative perspectives, young entrepreneurs stated that double deduction on expenses incurred on approved tourism-related training for the year of assessment 2020 is not helpful. Young firms are not able to spend on training as they do not have ample cash. Another policy that does not welcome by respondents is allowable expense deduction of up to RM300,000 on renovation and refurbishment cost incurred from the 1st of March 2020 to the 31st of December 2021. Young entrepreneurs viewed that renovation is a luxury, short-term survival is at stake, so this strategy does not give them an advantage in tax saving.

Although young entrepreneurs appreciate the deferment of loan, $80 \%$ of the respondents are very much concerned about their ability to service loans and pay tax after the moratorium period is lifted. This is because young firms' business is at the infant stage, struggling with unstable and inconsistent revenue. Many entrepreneurs are still exploring potential opportunities around. Some even just established the business beginning of the year 2020, just-in-time to ride with the pandemic wave. No one could predict when this pandemic will end. 
Table 1: Descriptive statistics

\begin{tabular}{|c|c|c|c|c|c|}
\hline Data & Number & Male & Percentage (\%) & Female & Percentage (\%) \\
\hline Gender & 25 & 7 & 28.0 & 18 & 72.0 \\
\hline Incorporated business & 10 & 5 & 50.0 & 5 & 50.0 \\
\hline Unincorporated business & 15 & 2 & 13.3 & 13 & 82.7 \\
\hline Number of employees (<10) & 17 & 3 & 17.6 & 14 & 82.4 \\
\hline Number of employees (>=10) & 8 & 4 & 50.0 & 4 & 50.0 \\
\hline
\end{tabular}

Source: Compiled and calculated by authors

From the positive perspectives, Government's WSP relieved young entrepreneur's burden to some extent in the short run. Many young entrepreneurs encountered a delay in the claims after the first two entitlements. Young Entrepreneurs also accolade the government's monthly tax deferment scheme and revision of tax estimate and six-month moratorium loan instalments by financial institutions. With these strategies, companies have extra money to roll for their labours and their expenses. The government also made it mandatory for employers who signed up for the wage subsidy programme (WSP) program not to lay off their employees until December 2020. These motives could also reduce the number of employees being laid off due to lockdown and slow business cycle and volume after movement control order (MCO) is lifted.

Another positive side from the economic stimulus packages via an online platform such as special Penjana discounts for the entrepreneur to commercialise their product and services in Shopee. The young entrepreneurs who are leaders are resilience and able to adapt to change rapidly because they are technology savvy. With the aid of digital technology, most young entrepreneurs used the social media platform to promote their products and services and consequently increase visibility. They also adopt cashless transactions via Touch \& Go e-wallet, Grab Pay, online payment, etc. Live marketing sessions also received positive feedback from customers. With this catalyst, young firms can survive in this storm and build resilience to chart a path to longer-term recovery.

Some suggestions and recommendations have been given by young entrepreneurs on how Malaysia can recover from the excess government expenditures during the COVID-19, specifically with the dampening oil price. The most expressed opinion is to reintroduce Goods and Services Tax (GST) once the pandemic is over. Meanwhile, a few young entrepreneurs suggested that the government impose a tax on stock market investment gain. Currently, gain from investment in Bursa Malaysia is non-taxable as it is capital receipt.

Malaysia is always running at a budget deficit. Malaysia Finance Minister forecasted the deficit for the year 2020 to be $5.8 \%$ to $6 \%$ of GDP with economic stimulus packages' execution. Generally, most young entrepreneurs voiced out that government should not be too generous in offering the tax incentives packages, particularly to those who have been blacklisted in tax evasion, non-compliance of Employee Provident Fund (EPF) and SOCSO payments or late in paying tax. With the deployment of an intelligence system, the government should be able to qualify the applicants. We used the USA government's case, which urged their citizens to submit their income tax report for the past two years to get any tax incentives and asked the respondents whether Malaysia should implement the same method to reduce government expenditure. Surprisingly, $72 \%$ of them believe that the Malaysia government should implement the same measure as the USA government.

\section{Conclusions}

The COVID-19 pandemic has a devastating impact on Malaysia's economy, with a greater severity degree on SMEs, particularly to young entrepreneurs whose business life cycle is at the infancy stage. It has dampened those well-doing business and aggravated the problems of those low performing business. Generally, the result indicates that the economic stimulus packages are effective as a shortterm strategy. Specifically, this study found that WSP, deferment of monthly tax payment and bank's moratorium are greatly valued by young entrepreneurs, among all stimulus packages. Contradictory, 
double deduction on training expenses and deductible renovation spending were not beneficial for young entrepreneurs because they do not have much reserve to spend during this challenging time. In other words, it is undoubtedly that the government's stimulus package can stop the bleeding in a short period. However, young firms face numerous surviving challenges as they do not have a huge capital to back up, nor have vast experiences to manoeuvre the pandemic.

With the new normal in the era of the COVID-19 pandemic, young entrepreneurs are encouraged to explore business opportunities. Take advantage of the upsurge in online business, for those already advertised on the website, perhaps should consider improving the website. Whereas, for those who have yet to make use of the e-commerce website, do seriously consider this platform and develop the product's competitive edge. Suppose this pandemic continues, and the government wishes to implement other incentives. In that case, this study proposes that a filtration process to be in place to exclude those who have a bad record of evading tax and not complying with EPF and SOCSO contributions. Besides, it is also recommended that young entrepreneurs apply for PENJANA's microfinancing capped at RM50,000 per enterprise with interest as low as 3.5\% per annum and priority is given to women entrepreneurs. This study collects viewpoints from a small sample of young Malaysian entrepreneurs. Future study is encouraged to increase the sample size and perform a comparison with established firms which is at the growth or maturity stages. In addition, the future study may examine the critical success factors for young firms to navigate through this pandemic.

\section{Acknowledgement:}

This paper is funded by Universiti Sains Malaysia's Bridging (Incentive) Research Grant 304/ PMGT/ 6316562 and School of Management, Universiti Sains Malaysia. Special thanks to Nur Fatin Nafiessa Binti Mazzuan, Vasunthra Reddy A/P Subramaniam, Yashwiny A/P Narayanan and Zafirah Izzati Binti Ahmad Johari, for data collections. This research is conducted while the third author is on sabbatical leave.

\section{References}

1. Association of Chartered Certified Accountants. (2020). Covid-19 Global Survey: Inside businessimpacts and responses. London, United Kingdom.

2. Bayer, C., Born, B., Luetticke, R., \& Müller, G. J. (2020). The Coronavirus Stimulus Package: How Large is the Transfer Multiplier? In CEPR Discussion Paper No. DP14600.

3. Carpenter, R. E., \& Petersen, B. C. (2002). Capital Market Imperfections, High-Tech Investment, and New Equity Financing. The Economic Journal, 112(477), 54-72. https://doi.org/10.1111/14680297.00683

4. Cooley, T. F., \& Quadrini, V. (2001). Financial Markets and Firm Dynamics. American Economic Review, 91(5), 1286-1310. https://doi.org/10.1257/aer.91.5.1286

5. Doorey, D. J. (2020). COVID-19 and Labour Law : Canada. Italian Labour Law E-Journal, 13(1S). https://illej.unibo.it/article/view/10843

6. Effendi, M. I., Sugandini, D., \& Istanto, Y. (2020). Social Media Adoption in SMEs Impacted by COVID-19: The TOE Model. The Journal of Asian Finance, Economics and Business, 7(11), 915-925. https://doi.org/10.13106/jafeb.2020.vol7.no11.915

7. Fitriasari, F. (2020). How do Small and Medium Enterprise (SME) survive the COVID-19 outbreak? Jurnal Inovasi Ekonomi, 5(02), 53-62. https://doi.org/10.22219/jiko.v5i3.11838

8. González, M., Guzmán, A., Pombo, C., \& Trujillo, M.-A. (2013). Family firms and debt: Risk aversion versus risk of losing control. Journal of Business Research, 66(11), 2308-2320. https://doi.org/10.1016/j.jbusres.2012.03.014

9. Guiso, L. (1998). High-tech firms and credit rationing. Journal of Economic Behavior \& Organization, 35(1), 39-59. https://doi.org/10.1016/S0167-2681(97)00101-7

10. Huynh, K. P., \& Petrunia, R. J. (2010). Age effects, leverage and firm growth. Journal of Economic Dynamics and Control, 34(5), 1003-1013. https://doi.org/10.1016/j.jedc.2010.01.007 
11. Nason, R. S., \& Patel, P. C. (2016). Is cash king? Market performance and cash during a recession. Journal of Business Research, 69(10), 4242-4248. https://doi.org/10.1016/j.jbusres.2016.03.001

12. Qureshi, M. I., Khan, N., Qayyum, S., Malik, S., Hishan, S. S., \& Ramayah, T. (2020). Classifications of Sustainable Manufacturing Practices in ASEAN Region: A Systematic Review and Bibliometric Analysis of the Past Decade of Research. Sustainability, 12(21), 8950. https://doi.org/10.3390/su12218950

13. Rahman, H. A., \& Hassan, R. (2020). Cashless Transactions Through Ecommerce Platform in the Post-Covid-19. International Journal of Research and Innovation Management, 6(1), 1-12.

14. The Edge Markets. (2020). IMF revises Malaysian 2020 GDP contraction to $3.8 \%$ from $1.7 \%$. https://www.theedgemarkets.com/article/imf-revises-malaysia-2020-gdp-forecast-38contraction

15. Tsoukas, S. (2011). Firm survival and financial development: Evidence from a panel of emerging Asian economies. Journal of Banking \& Finance, 35(7), 1736-1752. https://doi.org/10.1016/j.jbankfin.2010.12.008

16. Vithessonthi, C., \& Tongurai, J. (2015). The effect of firm size on the leverage-performance relationship during the financial crisis of 2007-2009. Journal of Multinational Financial Management, 29, 1-29. https://doi.org/10.1016/j.mulfin.2014.11.001

17. Voon, Z. Y. (2020). Struggle of Malaysian SMEs During the COVID-19 Pandemic. KSI Strategic Institute for Asia Pacific. 